\section{Effect of Dentin Preparation Mode on the Bond Strength Between Human Dentin and Different Resin Cements}

Lara Almeida Cyrillo Cerqueira, Ana Rosa Costaㄹ, Ana Maria Spohr ${ }^{3}$, Eduardo Miyashita $^{4}$, Benito André Silveira Miranzi ${ }^{5}$, Saturnino Calabrez Filho', Lourenço Correr-Sobrinho ${ }^{2}$, Gilberto Antonio Borges ${ }^{1}$

The aim was to evaluate the influence of different dentin preparation mode in the smear layer characteristics $(\mathrm{SL})$, hybrid layer $(\mathrm{HL})$, and microtensile bond strength $(\mu \mathrm{TBS})$ to dentin with two resin cements. The occlusal dentin of 120 third molars was exposed. The teeth were divided into 4 groups $(n=30)$ according to the dentin preparation mode: 1- fine grain diamond bur; 2 - coarse grain diamond bur; 3 - multi laminate carbide steel bur; and, 4- ultrasonic CV Dentus diamond bur. Each treated dentin group was divided into 2 sub-groups $(n=15)$ according to the resin cement: (1) RelyX U200 and (2) RelyX ARC. Resin composite blocks were cemented on dentin. After storage at $370 \mathrm{C}$ for 24 $\mathrm{h}$, beams with a cross section area of $1.0 \mathrm{~mm}^{2}$ were obtained, and tested in a universal testing machine at a crosshead speed of $0.5 \mathrm{~mm} / \mathrm{min}$. Two additional teeth for each sub-group were prepared to analyze the SL and HL on a scanning electron microscopy. According to Kruskal-Wallis test and Dunn tests, there was no significant difference in $\mu$ TBS among the rotary instruments within each resin cement group. RelyX ARC obtained higher $\mu$ TBS values compared to RelyX U200 ( $p<0.05)$. RelyX ARC formed evident $\mathrm{HL}_{\text {, }}$ which was not observed for RelyX U200. The dentin mode preparation did not influence the $\mu$ TBS of the resin cements. The SL was different for all instruments. The cementing agent is more determinant in the hybrid layer formation and bond strength to dentin than the instruments applied on dentin.

\author{
'Department of Restorative \\ Dentistry, Dental Materials and \\ Restorative, UNIUBE - Universidade \\ de Uberaba, Uberaba, MG, Brazil \\ ${ }^{2}$ Dental School, Dental Materials \\ Department, UNICAMP - \\ Universidade Estadual de \\ Campinas, Piracicaba, SP, Brazil \\ ${ }^{3}$ Department of Dental Materials, \\ PUCRS - Pontifícia Universidade \\ Católica do Rio Grande do Sul, \\ Porto Alegre, RS, Brazil \\ ${ }^{4}$ Department of Dentistry, \\ UNIP - Universidade Paulista, \\ São Paulo, SP, Brazil \\ ${ }^{5}$ Department of Endodontics \\ and Restorative Dentistry, \\ UNIUBE - Universidade de \\ Uberaba, Uberaba, MG, Brazil
}

Correspondence: Gilberto Antonio Borges, Avenida Nene Sabino 1801, 38055-500 Uberaba, MG, Brasil. Tel:+55-34-3319-8800 e-mail: gilbrazilian@gmail.com

Key Words: dentin preparation mode, resin cements, smear layer, hybrid layer, microtensile bond strength.

\section{Introduction}

In the last decades, the resin cements became more popular and reliable. Their evolution has resulted in different kind of materials that vary mostly in the manner of application, as well as some differences in composition (1). One of the simplest and more accepted manners to classify the resin cements is dividing them in resin cements that require adhesive system application, known as conventional resin cements, and those that do not require any material before using, known as self-adhesive resin cements (2).

Self-adhesive resin cements have been used in a large range for all kinds of indirect restorations. They contain acid monomers that remove partially the smear layer, resulting in micro-mechanical retention to the tooth structure. Furthermore, it has been defended that there is a reaction between phosphoric acid monomers and hydroxyapatite of the dental hard tissues. The main benefits of these resin cements are the facility of application, low postoperative sensitivity, and good tolerance to moisture (3). In contrast, conventional resin cements require surface pretreatment with etching followed by application of a bonding system.

Due to the use of a bonding system, the luting procedure with conventional resin cements form the interlocking structure known as hybrid layer, presenting good bonding and longevity (4). However, in spite of being extensively used nowadays, the self-adhesive resin cements are still progressing and only one brand has been studied more extensively (1). Furthermore, no hybridization was detected for the self-adhesive resin cements (4) and the bond strength was lower compared to the conventional resin cements $(5,6)$. Thus, more studies would bring important information regarding its bond capability to dental substrate, especially in some issues such as bond strength to dentin after the application of different instruments to finish the tooth preparation.

Smear layer is created by the cutting process of tooth structures with any kind of dental instrument and is considered as a very important barrier against fluid diffusion of oral or dental materials substances to the dental pulp (7). The strategies to create a stable bond has changed and progressed considerably in the last decades (8). The way the dentin surface is prepared and finished has an important role on the bond strength, and in the stability and reliability of this bond (9). The dentin surface regularity is dependent on the instrument used, and the marginal fit of an indirect restoration is also influenced by tooth preparation characteristics, which depends on the 
instrument applied on the tooth (10).

The dentist uses high-speed instruments to remove great quantity of dental tissue, and low speed to finish the preparation before taking an impression, because a smoothest surface is easier to copy and the final fitting of the restoration is better (11). Several studies have been carried out to evaluate the influence of the type of instrument, the speed, and the surface roughness among other properties on the bond strength of adhesive materials to dentin $(9,10,12-14)$. In this sense, one of the newest ways to prepare a crown is the use of ultrasonic instruments, especially on the surfaces that are in contact with gingiva. It has been shown that the preparation mode does not affect the bond strength with adhesive systems and direct composite resins (12). On the other hand, the influence of finishing preparation mode has not been evaluated with indirect restoration, especially with self-adhesive resin cement. As the ultrasonic instrument has been used to finish preparations in prosthetic dentistry, and with the increasing demand for use of self-adhesive resin cements, the evaluation of this interaction is important to greater understanding.

The aim was to evaluate, in vitro, the influence of different dentin preparation modes in the smear layer characteristics, hybrid layer formation, and microtensile bond strength ( $\mu \mathrm{TBS}$ ) to dentin with two resin cements. The null hypothesis is that the dentin preparation mode does not interfere in the smear layer characteristics, in the hybrid layer formation, and in the $\mu$ TBS of two different resin cements.

\section{Material and Methods}

\section{Tooth Preparation and Cementing Procedures}

This study was approved by the Research Ethic Committee \#27584814.2.0000.5145. One hundred twenty intact recently extracted human molars were collected, selected, stored in $0.1 \%$ thymol for 1 month. After that, they were stored in distilled water at $4^{\circ} \mathrm{C}$ until use. The occlusal enamel was sectioned perpendicular to the tooth long axis in a low-speed diamond saw machine (Isomet 1000; Buehler Ltd., Lake Bluff, IL, USA) to expose the subjacent dentin. Dentin was wet ground flat with 340 - and 600-grit silicon carbide paper until a uniform enamel-free dentin surface was obtained. The root of each tooth was removed about $2 \mathrm{~mm}$ above the cementum-enamel junction using the same saw machine cut parallel to the occlusal surface. Following, the teeth were randomly divided into four groups $(n=30)$, according to the dentin preparation mode: multi-laminate carbide steel bur (\#284 KG Sorensen, Barueri, SP, Brazil), fine grain diamond bur (\#3098 F KG Sorensen), coarse grain diamond bur (\#3098 KG Sorensen), and CV Dentus ultrassonic diamond bur E1 (CV Dentus, Sao José dos Campos, SP, Brazil).

The teeth within each group were divided into two sub-groups ( $n=15)$ according to the cement agent used to bond resin composite blocks (Tetric Ceram, Ivoclar-Vivadent, Ellwangen, Germany), built up in 2-mm-thick increments and photo activated using a LED light-curing unit at 1300 $\mathrm{mW} / \mathrm{cm}$ (Bluphase, Ivoclar-Vivadent, Amherst, NY, USA). The output power was checked with digital LED radiometer by Demetron (SDS Kerr, Middleton, WI, USA). The resin cements studied were RelyX U200 (3M-ESPE, St Louis, MN, USA), and RelyX ARC (3M-ESPE). The resin cements were manipulated and applied following the manufacturer's instructions (Table 1).

\section{Microtensile Bond Strength ( $\mu$ TBS)}

After the cementing procedures, all specimens were stored in distilled water at $37{ }^{\circ} \mathrm{C}$ for $24 \mathrm{~h}$. Each specimen was sectioned perpendicular to the bonding interface area to obtain beams with a cross section area of approximately $1.0 \mathrm{~mm}^{2}$ using a water-cooled diamond blade (EXTEC Corporation, Enfield, CT, USA) in a low-speed saw machine (Isomet 1000, Buehler Ltd.). The cross-sectional area of the bond interface of each beam was measured using a digital caliper (Mitutoyo Corporation, Tokyo, Japan). The beams were submitted to $\mu$ TBS test in a universal testing machine (EMIC DL3000, São José dos Pinhais, Brazil) with a load

Table 1. Cementing procedures

\begin{tabular}{|c|c|}
\hline Resin Cement & Procedures \\
\hline RelyX U200 & $\begin{array}{l}\text { (1) Dentin treatment: Cleaning with pumice power and water. Air dry. } \\
\text { (2) Equal quantities of base and catalyst paste of the resin cement was dispensed on a paper block } \\
\text { and mixed for } 10 \text { s. Following, the resin cement was applied on the composite resin block surface } \\
\text { and a Gilmore needle (bigger) was loaded on the resin composite block placed on dentin. } \\
\text { (3) The resin cement excess was removed. } \\
\text { (4) Photoactivation was carried out for } 40 \mathrm{~s} \text { in each face with a LED (Blue Phase). }\end{array}$ \\
\hline RelyX ARC & $\begin{array}{l}\text { (1) Dentin treatment: Cleaning with pumice power and water. Air dry. } \\
\text { (2) } 37 \% \text { phosphoric acid application for } 15 \mathrm{~s} \text {, rinse for } 30 \mathrm{~s} \text {, followed by the moisture control with absorbent paper. } \\
\text { (3) Single Bond Universal adhesive was mixed with the OPC bio activator and applied with a microbrush for } 10 \mathrm{~s} \text {. } \\
\text { (4) The resin cement (RelyX ARC) was mixed and the application was carried out as described for RelyX U200. }\end{array}$ \\
\hline
\end{tabular}


cell of $50 \mathrm{kgf}$ at a crosshead speed of $0.5 \mathrm{~mm} / \mathrm{min}$ until failure. The $\mu$ TBS was expressed in MPa. Beams at specimen peripheries were discarded. The tooth was considered as experimental unit ( $n=15$, per group). The $\mu$ TBS data were submitted to the non-parametric Kruskal-Wallis test and the post hoc Dunn test $(p<0.05)$.

After the $\mu \mathrm{TBS}$, the fractured surfaces of the specimens were visually examined with a stereomicroscope (Olympus Corp., Tokyo, Japan) at $40 x$ to classify the failure mode that occurred during the debonding procedure. The failures were classified as follows: adhesive (failure in the interface between dentin and resin cementcohesive (failure exclusively within dentin or resin composite); mixed (adhesive failure and cohesive failure in resin cement).

\section{Scanning Electron Microscopy (SEM) Analysis of Smear layer}

Two additional teeth per group of dentin preparation mode received a grove made with diamond blade that allowed a section in two halves. Each half was cleaned in ultrasonic bath and mounted on coded brass stubs, gold coated with a sputter coater (Balzers-SCD 050; Balzers Union Aktiengeselischaft Füstentun, Liechtentein) for $180 \mathrm{~s}$ at $40 \mathrm{~mA}$. They were examined using SEM (LEO 435 VP; Cambridge, England) operated at $20 \mathrm{Kv}$ by the same operator.

\section{SEM Analysis of Hybrid Layer}

One additional restored tooth per cemented sub-group was vertically sectioned in $2 \mathrm{~mm}$ slices (about 4 slices per group), and then embedded in epoxy resin (Buehler, Lake Bluff, IL, USA). After each storage time, the slices were wet-polished using 600, 1200 and 2000-grit SiC papers (Norton SA, São Paulo, SP, Brazil) and with decreasingly fine diamond compounds $(3 \mu \mathrm{m}, 1 \mu \mathrm{m}, 1 / 2 \mu \mathrm{m}, 1 / 4 \mu \mathrm{m}$ Metadi II, Buehler, Lake Bluff, IL, USA). After each polishing step the specimens were ultrasonically washed for 10 min, demineralized with liquid $50 \% \mathrm{H}_{3} \mathrm{PO}_{4}$ for $5 \mathrm{~s}$, rinsed in distilled water, deproteinized with $2.5 \% \mathrm{NaOCl}$ for 10 min. Following, they were cleaned in deionized water and placed in a hermetic recipient that contained colloidal silica. After $24 \mathrm{~h}$ the specimens were gold coated with a sputter coater (Balzers-SCD 050) for $180 \mathrm{~s}$ at $40 \mathrm{~mA}$ and examined using SEM (LEO 435 VP) operated at $20 \mathrm{KV}$ by the same operator.

\section{Results}

\section{Microtensile Bond Strength ( $\mu$ TBS)}

The $\mu$ TBS values and the respective standard deviations are shown in Table 2. There was no significant difference in $\mu$ TBS among the instruments within each resin cement group. Regardless of the type of instrument, RelyX ARC obtained significant higher $\mu$ TBS values compared to RelyX U200.

Mixed failure was observed in RelyX ARC groups and adhesive failure was predominant in RelyX U200 groups.

\section{SEM Analysis of Smear Layer}

Figure 1 shows the SEM of the smear layer for the different dentin preparation modes. A thick smear layer was produced at the bur-cut dentin surface with course diamond bur, and a thin smear layer was produced by fine diamond bur. A thin and more regular smear layer was obtained with multi-laminate carbite steel bur. A very thin and dense smear layer covered the dentin surface when ultrasonic diamond bur was applied.

\section{SEM Analysis of Hybrid Layer}

The SEM characterization of the bonding interfaces for different dentin preparation modes and resin cement agents is presented in Figure 2 and 3. There was evidence of hybrid layer formation and many resin tags for RelyX ARC in all groups (Fig.2). For RelyX U200, there was no hybrid layer, neither resin tags in all groups. Gaps occurred between the dentin substrate and the bottom of RelyX U200 (Fig. 3).

\section{Discussion}

The null hypothesis that the dentin preparation mode does not interfere in the smear layer characteristics was rejected. In the present study, all preparations with the instruments were carried out with abundant refrigeration as it is done in a clinical situation. It was planned to create a condition that even was laboratorial, the results could be well related to the clinic. The SEM images showed the smear layer being a uniform and amorphous structure which seemed to occlude the orifices completely of the dentinal

Table 2. Microtensile bond strength means (MPa) and standard deviations (SD) of the groups

\begin{tabular}{lc}
\hline Groups & Means $(\mathrm{MPa})$ and SD \\
\hline RelyX ARC + multi laminate bur & $31.97 \pm 10.06 \mathrm{~A}$ \\
RelyX ARC + fine grain diamond bur & $29.24 \pm 8.59 \mathrm{~A}$ \\
RelyX ARC + ultrasonic diamond bur & $28.98 \pm 7.57 \mathrm{~A}$ \\
RelyX ARC + coarse grain diamond bur & $27.26 \pm 11.34 \mathrm{~A}$ \\
RelyX U200 + multi laminate bur & $16.53 \pm 7.97 \mathrm{~B}$ \\
RelyX U200 + coarse grain diamond bur & $13.82 \pm 6.81 \mathrm{~B}$ \\
RelyX U200 fine grain diamond bur & $10.65( \pm 4.68) \mathrm{B}$ \\
RelyX U200 + ultrasonic diamond bur & $9.19( \pm 3.48) \mathrm{B}$ \\
\hline
\end{tabular}

*Different capital letters in column indicate statistically significant differences $(\mathrm{p}<0.05)$. 

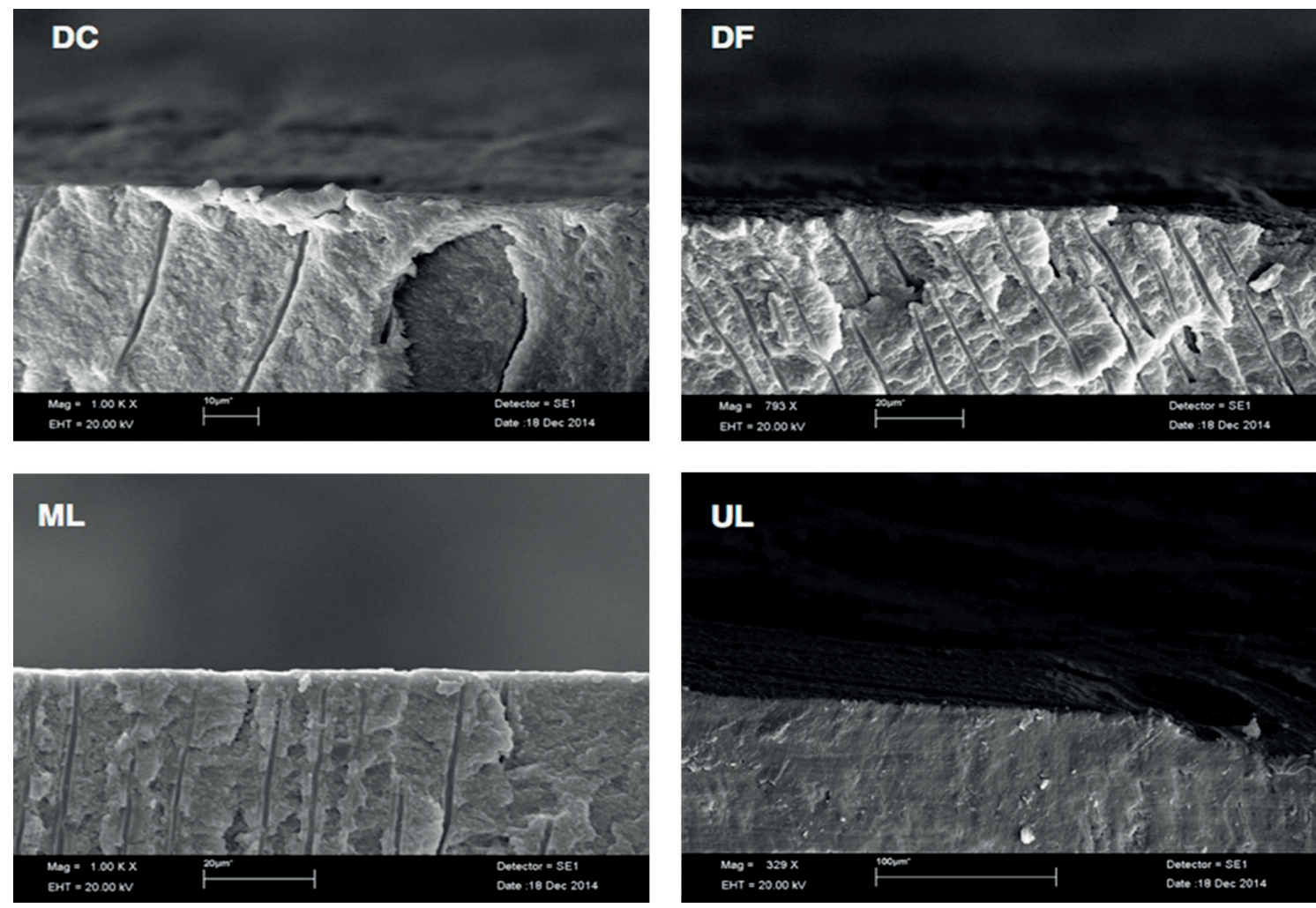

Figure 1. SEM micrographs of cross-sectioned dentin surfaces prepared with coarse diamond bur (DC), Fine diamond bur (CF), Multi-laminate diamond bur (ML) and Ultrasonic diamond bur (UL). A thick smear layer was produced at the bur-cut dentin surface for CD; a thin smear layer can be observed to FC; a thin but more regular smear layer is seen to ML; a very thin and dense smear layer covered the dentin surface to US.
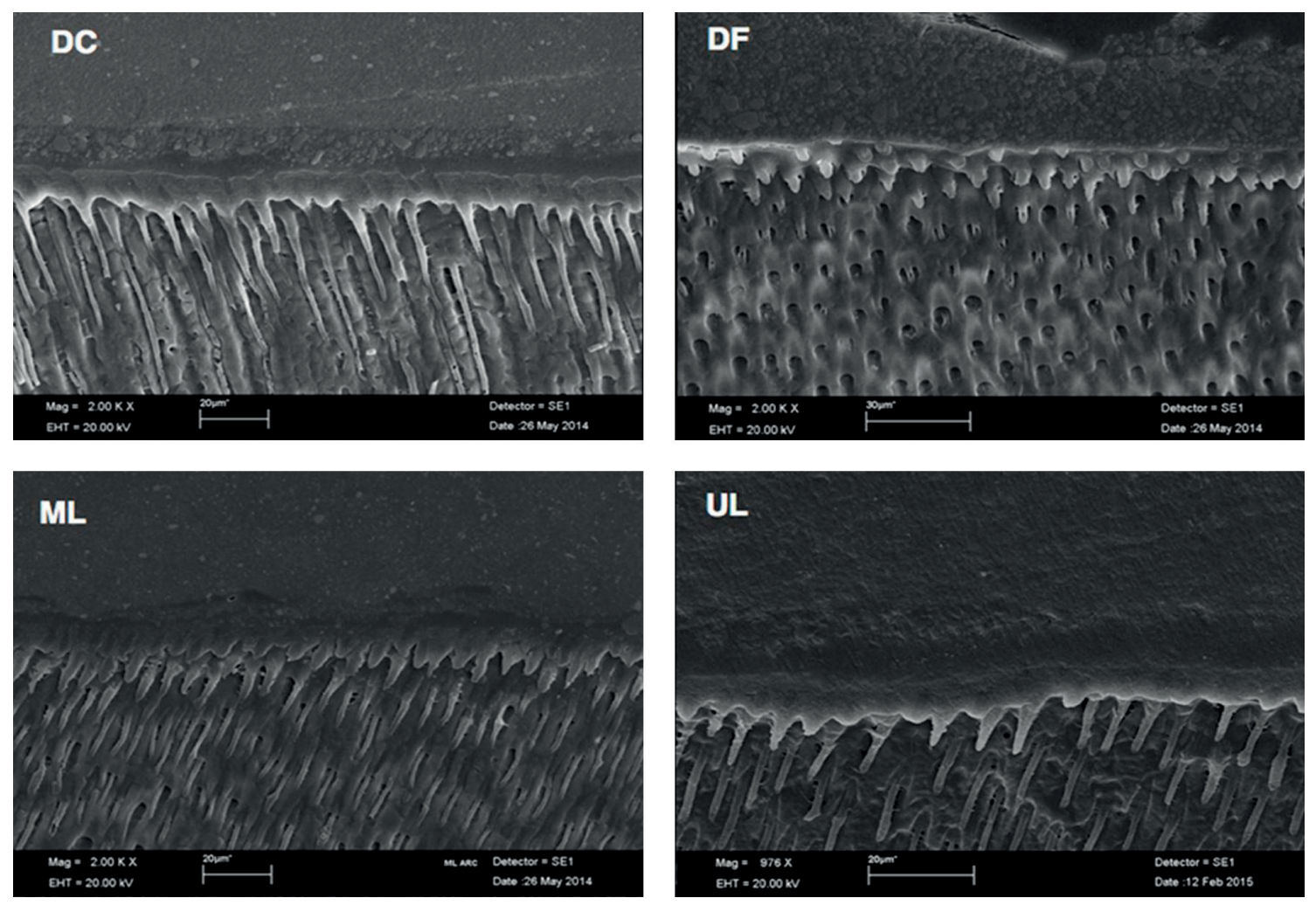

Figure 2. SEM micrographs of bonding interface with RelyX ARC. Coarse diamond bur (DC), Fine diamond bur (CF), Multi laminate diamond bur (ML) and Ultrasonic diamond bur (UL). Hybrid layer formation and resin tags can be observed in all groups. 
tubules under all instruments evaluated (Fig.1). The smear layer was thicker when the preparation was done with the coarse diamond bur, producing a more irregular surface with groves compared to the remaining modes. This finding corroborates with another study (15). The fine diamond bur produced smaller and shallower groves, and the multi-laminate bur produced a more uniform smear layer. However, the characteristic of ultrasonic diamond bur was different from the others since the smear layer was denser with thicker obliteration compared to the remaining ones. It has been shown that the quantity and quality of smear layers vary widely, depending upon whether the dentin is cut wet or dry, and the type of instrument employed (16).

Although the instruments had formed smear layers with different characteristics, there was no statistical difference in the $\mu$ TBS values among the instruments for each of the resin cement. Therefore, the null hypothesis that the dentin preparation mode did not interfere with the $\mu$ TBS values was accepted. However, the multi-laminate bur group had higher $\mu$ TBS for both resin cements, even though it was not statistically different from the other instruments. Probably the thin and more regular smear layer produced

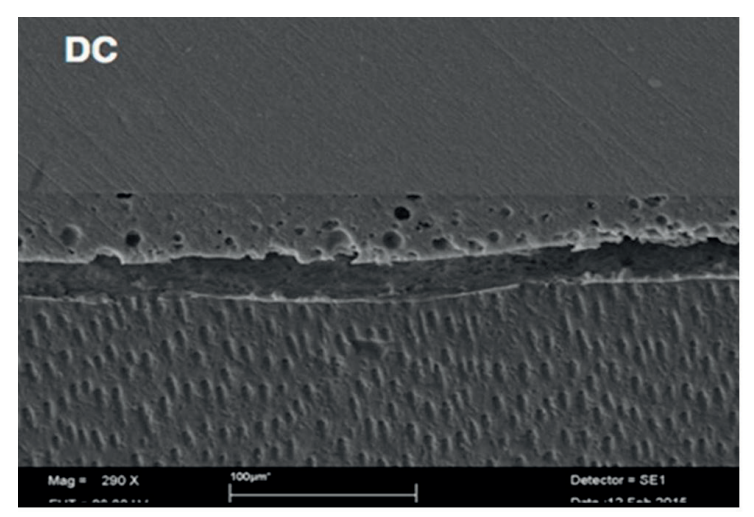

of RelyX U200, a thin and more regular smear layer could facilitate the action of the acid monomer on the dentin surface. Other studies recommended the use of multilaminate carbide bur to finish the preparation because this type of bur produced a thinner smear layer as well as a smoother surface, and these would facilitate the etching and hybrid layer formation $(9,10)$.

The consulted literature did not show any evaluation with the CV Dentus ultrasonic diamond bur regarding to bond strength with resin cement. However, some studies have been done with direct composite resin with adhesive systems (14) and evaluated the cutting effectiveness, showing that ultrasonic diamond bur had less dental tissue invasion (13). In the present study, the ultrasonic diamond bur obtained comparable $\mu$ TBS to the other instruments. In a clinical point of view, some have advised that the preparation with the ultrasonic diamond bur should be done only in areas closer to the gingiva tissue, because the instrument cut the dental surface without cause any hurt in the soft tissue. In addition, the surface roughness of dentin prepared with the ultrasonic diamond bur can be improved by using a smaller grit size and a smooth tip, and as a result, the roughness approximates to the dentin prepared with a diamond bur (17). The grain size of the burs used in the present study was the same that the referred
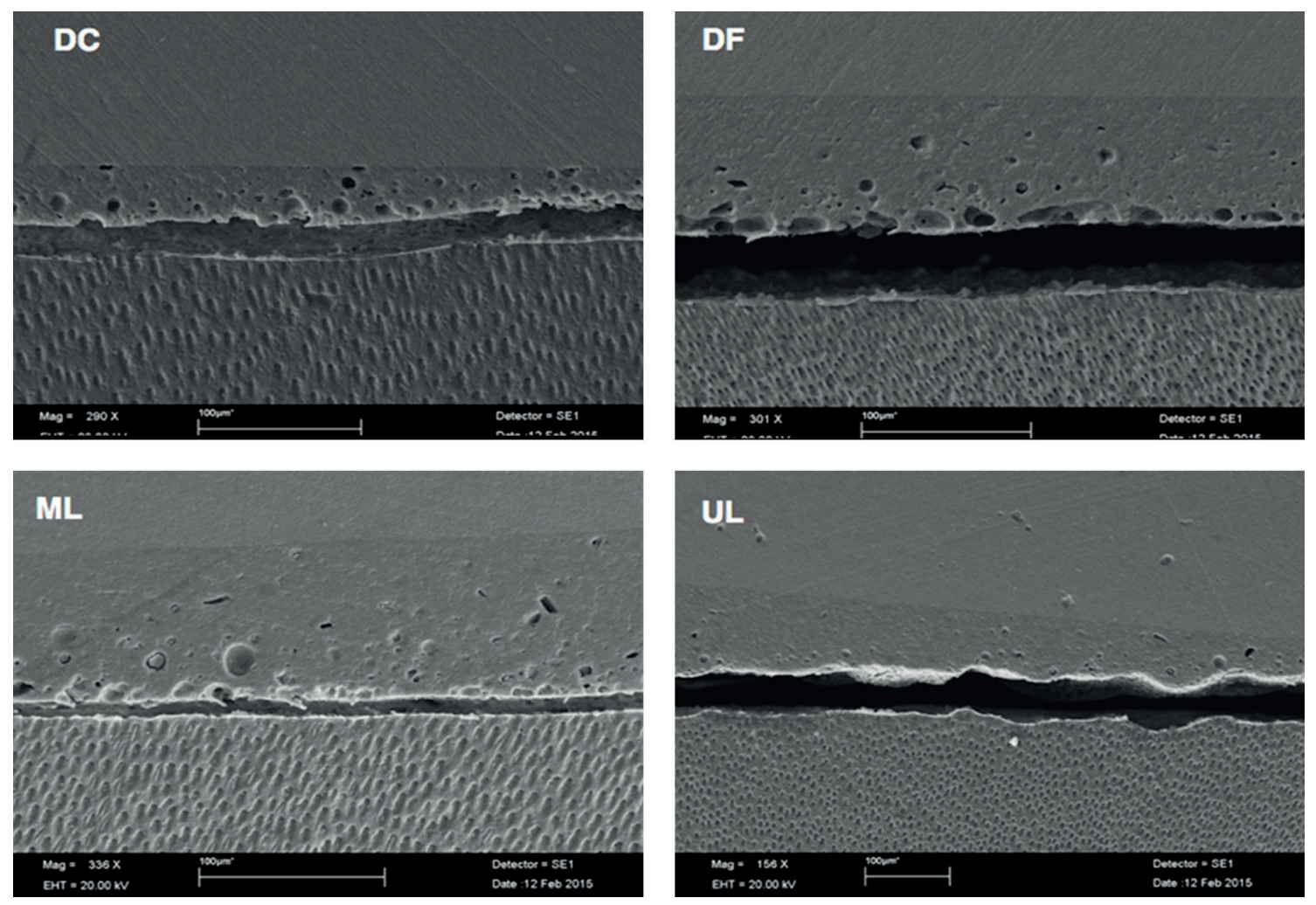

Figure 3. SEM photomicrographs of bonding interface with Rely XU200. Coarse diamond bur (DC), Fine diamond bur (CF), Multi laminate diamond bur (ML) and Ultrasonic diamond bur (UL). There is no evident hybrid layer formation. Gaps occurred between the dentin substrate and the bottom of the resin cement in all groups. 
study. Moreover, it has been shown that the extremely precise preparation margin with ultrasonic instruments improved the quality and accuracy of crown preparations, which may lead to better impressions and closer adaptation of restorations (18).

Hence, it might seen that there is no need to carry a bond strength test, but the area of preparation is also important in promoting a good bonding as well as sealing such a critical region. The manufacturer's recommendation is to use only the tip of the ultrasonic diamond bur. If the lateral part of the instrument is applied, the vibration creates a plastic deformation, and furthermore, it is difficult controlling pressure. In this sense, it was hard to prepare the large dentin area used in the present study, but the difficulty was related to the time spent and not with the technique itself. Thus, the results were not jeopardized.

Regardless of the instrument used, the hybrid layer and resin tags were evident in all RelyX ARC groups. Despite the differences in the characteristics of the smear layer formed by the different instruments, the 37\% phosphoric acid, previously applied to the Single Bond Universal adhesive system, causes the removal of the smear layer and smear plugs, the opening of the dentin tubules and demineralization of intertubular and peritubular dentin to a depth of approximately $5 \mu \mathrm{m}$ (19). Subsequently, the adhesive impregnates the demineralized region, forming a hybrid layer with evident thickness and the formation of resin tags due to the opening of the dentinal tubules (20) in all groups. On the other hand, the RelyX U200 self-adhesive resin cement did not form an evident hybrid layer neither resin tags. This result corroborates with other studies that evaluated the bond interface of self-adhesive resin cements using SEM $(21,22)$. The self-adhesive resin cements have acid monomers that do not have the same demineralization capacity of the smear layer and the underlying dentin as $37 \%$ phosphoric acid, and the interaction of this material with the dentin surface is more superficial (23).Therefore, the instruments used on the dentin were not determinant in the formation of the hybrid layer, but the cementing agents applied on dentin. Thus, the null hypothesis that the dentin preparation mode does not interfere in the formation of the hybrid layer was accepted.

In the RelyX U200 specimens, the SEM images always showed a gap between the resin cement and the dentin surface, which was not observed in the RelyX ARC specimens. These artifacts could be explained by the lack of hybrid layer and a bond strength that did not resist the stresses created by the specimen preparation such as the epoxy resin shrinkage and the vacuum formed in the sputter as well as in the scanning electron microscope chamber.

Comparing the $\mu$ TBS between the two resin cements, RelyX ARC, which is preceded by the application of adhesive system, showed higher $\mu$ TBS compared to RelyX U200 self-adhesive resin cement. This finding corroborates with other studies $(5,6)$. Mixed failures occurred in RelyX ARC groups and adhesive failures occurred in RelyX U200 groups, which is in accordance with the higher bond of the first one to dentin. Then, when cementing a restoration on a preparation that does not have frictional retention, the recommended resin cement should be the one that has prior application of an adhesive system, regardless of the type of instrument used. In this way, the hybrid layer and high bond strength can keep the restoration in place in a reliable manner. However, if the preparation does have a good frictional retention, the self-adhesive cement is well indicated, because the cohesive strength plays more important role than the bond strength itself.

Within the conditions of the present study, the following conclusions can be drawn: (1) the type of instrument (dentin mode preparation) did not influence the $\mu$ TBS within each resin cement group. However, for all type of instruments, the RelyX ARC resin cement showed higher values compared to RelyX U200; (2) thick smear layer was obtained with course diamond bur, and thin smear layer was obtained with fine grain diamond bur and multilaminate carbite steel bur. Ultrasonic diamond bur produced a very thin smear layer. (3) the hybrid layer was evident only for RelyX ARC resin cement groups regardless of the instrument used.

\section{Resumo}

0 objetivo deste estudo foi avaliar a influência de diferentes modos de preparação da dentina nas características da smear layer (SL), da camada híbrida $(\mathrm{CH})$ e na resistência de união à microtração $(\mathrm{RU} \mu \mathrm{T})$ à dentina com dois cimentos resinosos. A dentina oclusal de 120 terceiros molares humanos foi exposta. Os dentes foram divididos em 4 grupos $(n=30)$ de acordo com o modo de preparação da dentina: 1 - ponta diamantada de granulação fina; 2 - ponta diamantada de granulação grossa; 3 - ponta de carboneto de aço multilaminada; 4 - ponta diamantada ultrassônica. Cada grupo foi subdividido em dois subgrupos $(n=15)$ de acordo com o cimento resinoso: (1) RelyX U200 e (2) RelyX ARC. Blocos de resina composta foram cimentados na dentina. Após armazenamento a $37{ }^{\circ} \mathrm{C}$ por $24 \mathrm{~h}$, as amostras foram cortadas para obter palitos com área de $1,0 \mathrm{~mm}^{2}$, os quais foram testados em máquina de ensaio universal com velocidade de $0,5 \mathrm{~mm} / \mathrm{min}$. Dois dentes adicionais por subgrupo foram preparados para analisar as características da SL e da $\mathrm{CH}$ em microscópio eletrônico de varredura. De acordo com o teste de Kruskal-Wallis e o teste de Dunn, não houve diferença significativa na RU $\mu$ T entre os instrumentos rotatórios para cada cimento resinoso. RelyX ARC obteve maiores valores de RUHT em comparação ao RelyX U200 $(p<0,05)$. RelyX ARC formou uma CH evidente, o que não foi observado para o RelyX U200. 0 modo de preparação da dentina não influenciou na RU $\mu \mathrm{T}$ dos cimentos resinosos. A SL foi diferente para todos os instrumentos. 0 agente de cimentação foi mais determinante na formação da camada híbrida e na resistência de união do que os instrumentos utilizados para preparar a dentina.

\section{References}

1. Weiser F, Behr M. Self-Adhesive Resin Cements: A Clinical Review. J Prosthodont 2015;24:100-108.

2. Manso AP, Silva NR, Bonfante EA, Pegoraro TA, Dias RA, Carvalho RM. Cements and adhesives for all-ceramic restorations. Dent Clin North 
Am 2011;55:311-332.

3. Ferracane JL, Stansbury JW, Burke FJ. Self-adhesive resin cements - chemistry, properties and clinical considerations. J Oral Rehabil 2010;38:295-314.

4. Aguiar TR, Vermelho PM, André CB, Giannini M. Interfacial ultramorphology evaluation of resin luting cements to dentin: a correlative scanning electronmicroscopy and transmission electron microscopy analysis. Microsc Res Tech 2013;76:1234-1239.

5. Lührs AK, Guhr S, Günay H, Geurtsen W. Shear bond strength of self-adhesive resins compared to resin cements with etch and rinse adhesives to enamel and dentin in vitro. Clin Oral Invest 2010;14:193199.

6. De Angelis F, Minnoni A, Vitalone LM, Carluccio F, Vadini M, Paolantonio $\mathrm{M}$, et al. Bond strength evaluation of three self-adhesive luting systems used for cementing composite and porcelain. Oper Dent 2011;36:626-634.

7. Pashley DH, Pashley EL. Dentin permeability and restorative dentistry: astatus report for the American Journal of Dentistry. Am J Dent 1991;4:5-9.

8. Tjäderhane $L$, Nascimento FD, Breschi L, Mazzoni A, Tersariol IL, Geraldeli S, et al. Strategies to prevent hydrolytic degradation of the hybrid layer-A review. Dent Mater 2013;29:999-1011.

9. Ayad MF, Maghrabi AA, Saif RE, Garcia-Godoy F. Influence of tooth preparation burs on the roughness and bond strength of adhesives to human dentin surfaces. Am J Dent 2011;24:176-182.

10. Ayad MF, Johnston WM, Rosenstiel SF. Influence of dental rotary instruments onthe roughness and wettability of human dentin surfaces. J Prosthet Dent 2009;102:81-88.

11. Wahle JJ, Wendt SL Jr. Dentinal surface roughness: a comparison of tooth preparation techniques. J Prosthet Dent 1993;69:160-164.

12. Yiu CK, Hiraishi N, King NM, Tay FR. Effect of dentinal surface preparation on bond strength of self-etching adhesives. J Adhes Dent 2008;10:173-82.

13. Lima LM, Motisuki C, Corat EJ, Santos-Pinto L. Comparative cutting effectiveness of an ultrasonic diamond tip and a high-speed diamond bur. Minerva Stomatol 2009;58:93-98.
14. Mascarenhas Oliveira AC, Monti Lima L, Santos-Pinto L. Influence of cutting instruments and adhesive systems on hybrid layer formation. Minerva Stomatol 2012;61:57-63.

15. Bortolotto T, Ferrari M, Susin A, Krejci I. Morphology of the smear layer after the application of simplified self-etch adhesives on enamel and dentin surfaces created with different preparation methods. Clin Oral Investig 2009;13:409-417.

16. Gilboe DB, Svare CW, Thayerh E, Drennon DG. Dentinal Smearing: An investigation of the phenomenon. J Prosthet Dent 1980;44:310-316.

17. Sous M, Lepetitcorps $Y$, Lasserre JF, Six N. Ultrasonic sulcus penetration: a new approach for full crown preparations. Int J Periodontics Restor Dent 2009;29:277-287.

18. Ellis R, BennaniV, Purton D, Chandler N, Lowe B. The effect of ultrasonic instruments on the quality of preparation margins and bonding to dentin. J Esthet Restor Dent 2012;24:278-285.

19. Sarr M, Kane AW, Vreven J, Mine A, Van Landuyt KL, Peumans M et al. Microtensile bond strength and interfacial characterization of 11 contemporary adhesives bonded to bur-cut dentin. Oper Dent 2010;35:94-104.

20. Manfroi FB, Marcondes ML, Somacal DC, Borges GA, Júnior LH, Spohr AM. Bond strength of a novel one bottle multi-mode adhesive to human dentin after six months of storage. Open Dent J 2016;10:268277.

21. Al-Assaf $K$, Chakmakchi M, Palaghias G, Karanika-Kouma A, Eliades $\mathrm{G}$. Interfacial characteristics of adhesive luting resins and composites with dentine. Dent Mater 2007;23:829-839.

22. Monticelli F, Osorio R, Mazzitelli C, Ferrari M, Toledano M. Limited decalcification/diffusion of self-adhesive cements into dentin. J Dent Res 2008; 87:974-979.

23. Stona P, Borges GA, Montes MA, Júnior LH, Weber JB, Spohr AM. Effect of polyacrylic acid on the interface and bond strength of self-adhesive resin cements to dentin. J Adhes Dent 2013;15:221-227.

Received September 27, 2017 Accepted January 7, 2018 